\title{
THE JEWISH HISTORICAL INSTITUTE IN WARSAW AND ITS TREASURES
}

www.jewishinstitute.org.pl

\author{
Eleonora Bergman \\ Director, Jewish Historical Institute, Warsaw, Poland \\ lbergman@jhi.pl
}

\begin{abstract}
RESUMEN
El articulo presenta la historia y las actividades del "Jewish Historical Institute" de Varsovia. Comprende una corta descripción de sus departamentos y secciones, como también de algunas colecciones. Incluye ejemplos de los temas más sobresalientes. Las piezas que posee el "Jewish Historical Institute" son memoria de la vida y cultura judia, próspera en la Polonia de preguerra que fue sede de la mayor comunidad judía europea antes de la Segunda Guerra Mundial. Son de la máxima importancia para el estudio de la vida y la muerte de los judíos europeos.
\end{abstract}

Palabras Clave: historia judia, Varsovia, Holocausto, colección.

\begin{abstract}
The article presents the history and activities of the Jewish Historical Institute in Warsaw. There is a short description of its departments and sections and also of some collections, including examples of the most outstanding items. The holdings of the Jewish Historical Institute are the reminder of the thriving Jewish life and culture in prewar Poland, the site of the largest Jewish community in Europe before WWII. They are of the utmost importance for the study of life and death of European Jews.
\end{abstract}

KeY WORDS: Jewish History, Warsaw, Holocaust, Collection.

In 1878, when the Great Synagogue on Thomackie Street was built, it was the only progressive (they did not use the word: Reform) synagogue among Warsaw's several hundred Jewish houses of prayer, serving at that time the 200,000 strong Jewish population. The building of today's Jewish Historical Institute was originally built to house the Main Judaic Library of the Great Synagogue. 
During the opening ceremony, on April 22, 1936, Rabbi Moshe Schorr said about the Library that its goal should be seeking harmony between faith and knowledge, that it is to be "...for the sake of the living as well as future generations, for the glory of Jewry and embellishment of the capital." He also said on behalf of the Institute of Judaic Studies, established in 1928, which found its permanent seat in the Library building: "It is the most important center of research in the field of Jewish lore today. ...it should radiate from this building on the outside, creating lively contact with the widest strata of Jewish society ...[it should be] directed to listeners among the Jewish and Polish intelligentsia of all the strata of the capital." Rabbi Schorr pointed out the context for the new institutions, the Hebrew University established a few years earlier in Jerusalem: "At this solemn moment, our hearts and thoughts go to the land of our rebirth where a new center of spirit, a new Temple of Knowledge is built".

The Jewish Historical Institute (JHI), transformed from the Central Jewish Historical Commission (in existence starting in November 1944), found its permanent seat in 1947 literally on the ruins of the Institute of Judaic Studies and the Main Judaic Library. The building was restored with the help of the American Joint Distribution Committee.

Bernard (Ber) Mark, in his capacity of the JHI director, wrote in his editorial in the first issue of the Bulletin of the Jewish Historical Institute in March 1950: "The Jewish Historical Institute is nowadays the biggest Jewish academic institution in Europe." He defined it as "the institute of national memory." He also wrote that "being the only Jewish academic institution in Poland, the Institute considers its obligation to cover by research all of the Polish Jewish history".

Today the JHI defines itself as a successor of the Main Judaic Library, not just as a place of collecting, but also of lectures, meetings and exhibitions. To a certain extent it is also a successor of the Institute of Judaic Studies (the non-religious part of its curriculum). This reference includes the acceptance of tradition initiated by the founders of the Great Synagogue, whose origins go back to 1800 , and its Library, conceived about 1850 . This is the tradition of Jewish religion as interpreted by the $19^{\text {th }}$ century Progressive or Reform movement, with its culture of both Hebrew and local language and also the tradition of assimilation into the Polish society.

After WWII, the main goal of survivors who felt that their mission was to bear witness, was to gather testimonies, on the one hand, to the prewar Jewish life, and on the other, to the destruction of the Jews. The search for archival materials in abandoned ghettos and camps, for book collections in abandoned libraries, and for works of art was initiated by the Central Jewish Historical Commission and the Jewish Society for Promotion of Fine Arts (eventually included in the JHI) and has been continued since 1947 by the Jewish Historical Institute. It became a depository and a collector. Until this day it is the only academic level institution in Poland focused entirely on Jewish history, and, until recently, it was the only one of its kind in East Central Europe.

\section{- ARCHIVES}

The holdings of the ZIH Archives are of fundamental importance for the study of the history of Polish Jews. Over 60 per cent of these holdings concern the Second World War. The 
core of the collection are the documents saved and completed in the years 1944-1950 by the Central Jewish Historical Commission. The most valuable collections include: the Underground Archive of the Warsaw Ghetto, often referred to as the Ringelblum Archive; early testimonies of the Holocaust survivors and the documents of Jewish organizations set up after the end of German occupation, such as the Central Committee of Polish Jews, providing information on the condition of decimated Polish Jewish communities and their attempts at reviving Jewish life in post-war Poland. The Archives' holdings include registers of names from the camps, ghettos, post-war orphanages, registers of survivors, and identity documents which are very helpful in the genealogical research pursued at our Institute.

There are 110 archival collections; the last one on the list contains 28 legacies which were bequeathed by former staff members or their families. Archival collections are in various stages of processing. In case of the Holocaust related material, this work is supported by the Holocaust Memorial Museum in Washington, and by the Claims Conference. The Institute has its own laboratories: for paper conservation and for microfilming of archival materials.

Pre-1939 documents include papers of several important Jewish communities. In the files of Jewish Religious Community in Kraków there are: the statute of the Israelite Congregation with its successive revisions, and other associations' archival files from 1914-1939; abstracts of documents dating back to 1730; correspondence of the Jewish Community with the Senate of the Free City of Krakow (1822-1849); documents of the rabbinate and synagogues dating back to the late 19th century; documents of charity organizations, foundations, hospitals, schools, orphanages, etc. A separate group of documents includes those of Jewish associations and communities in Podgorze that after the First World War were annexed to Kraków.

The Breslau (Wroclaw) Jewish Community archive, founded in 1924, has been preserved almost in its entirety. It included documents also from other Silesian communities, as well as deposits from various institutions, synagogues and private collections. In 1943, Germans placed most of these materials in a building at one of the Wrockaw cemeteries, where they were found after 1945 .

There are also some materials from the Jewish Community in Berlin. These are documents confirming the privileges that had been bestowed upon the Brandenburg rabbis, decrees and regulations from the late 18 th and early 19th centuries, lists of rabbis and community leaders from 1812-1834, testaments bequeathing property to the community from 1817-1847, and community statutes from 1846-1907.

A very special group of documents, donated to JHI by the Polish Consulate in Haifa, are emigration passports of Polish Jews, who had left for Palestine before 1939.

The Holocaust era materials constitute about $60 \%$ of our archival holdings.

The most important of them is the clandestine Warsaw Ghetto Archive known by the name of the man who created it, Emanuel Ringelblum. This outstanding historian formed and directed 
a group whose main task was to document what life was like in the Warsaw ghetto - the largest ghetto in Nazi occupied Europe. The group also recorded any information they received from refugees and from those transferred from other areas of occupied Poland, as well as documenting the occupying power's policies and all aspects of life and death in the ghettos and camps. The Archive's materials, their two parts hidden on August 3, 1942, and in late February 1943, were found in the ruins of the ghetto on September 18, 1946 and December 1, 1950, respectively. There are 2045 archival files including about 6,000 documents on about 35,000 pages. These documents are the crucial source on the history of life and destruction of Polish Jews during WWII. In 1999, the Ringelblum Archive was added to the UNESCO "Memory of the World" register. Its complete inventory was prepared in 2003 in conjunction with the United States Holocaust Memorial Museum in Washington, D.C. It will be published later this year in English. All the collection has been conserved (it lasted 15 years) and then digitized.

Some other significant collections are listed and shortly described below:

Documentation of the American Jewish Joint Distribution Committee (Joint, AJDC) and the Jewish Self-Help organization. These two groups of documents contain materials from the AJDC headquarters in Poland, including the distribution of money from 1939 until its activities came to an end when the United States went to war in 1941. These are programmatic and organizational materials and memoranda regarding the situation of the Jewish population, and correspondence with diplomatic posts and AJDC offices in Europe, Red Cross offices, and about 500 Jewish communities; there are also lists of individuals who applied to emigrate.

Death certificates from the Warsaw ghetto. Despite the isolation, the inhabitants of the Warsaw ghetto were still subject to general census. Death certificates were passed by the Jewish Council to the City Council, and therefore they survived. Many of the 10,500 cards were partly damaged by fire during the 1944 Warsaw uprising. All of them have undergone some conservation procedure.

Letters from the Warsaw ghetto sent 1941 and 1942 by Rywka Finkelsztajn and her daughters, Estera and Aviva, to Chaim Finkelsztajn, her husband and their father, to New York. Chaim Finkelsztajn (1899-2001) was a Warsaw journalist of Zionist orientation, deputy of the editorin-chief of the Haynt daily; when WWII started he was in Basel at the Zionist congress. His wife Rywka and daughter Estera did not survive the Shoah. His other daughter, Aviva, survived outside the ghetto and in 1945 joined her father in the U.S. The letters were donated to ZIH by Aviva Blumberg (b. Finkelsztajn) in 2002.

Materials from the ghettos and documents from the Jewish Councils (Judenräte) in Będzin, Cęstochowa, Falenica, Jasło, Kamieńsk, Końskie, Kraków, Lochów, Międzyrzec Podlaski, Pińsk, Rawa Russka, Staszów, Warszawa, Włoszczowa.

Card catalog of over 3,000 Jewish prisoners-of-war. Starting in 1941 Jewish soldiers of the Polish army, held captive in various stalags in Germany, were brought to the camp at Lipowa Street in Lublin. On November 3, 1943, the prisoners from this camp and about 3,000 inmates of 
the Poniatowa and Trawniki camps, were taken by the Germans to Majdanek concentration camp and murdered there along with some 18,000 Jewish civilians.

Card catalog of prisoners in the Hasag Pelcery camp in Częstochowa (Hasag = the Hugo Schneider Aktiengesellschaft company. It had its main plant in Leipzig. It took over the factories in the former Central Industrial District and established forced labor camps for Jews at all of them). This is the only surviving list from that camp.

Diaries written during the years 1939-1945. This collection is constantly receiving new additions. It currently includes 330 items. In 2007 , a new revised archival catalogue of the collection was published.

Passports of German and Austrian Jews who were deported to the Lodz ghetto and died there. From October 17 through November 4, 1941, there were 19954 Jews from Austria, Czech Republic, Luxembourg and Germany deported to the Lodz ghetto. The death rate of their group was the highest in the ghetto.

Some of the materials developed after WWII are strictly complementary to those of the war time. Among them are 7,300 testimonies of Jews who survived the Holocaust, the great majority of which were written down during the years 1944-1948. Questionnaires for this project developed by the Central Jewish Historical Commission from 1944 and 1945 referred directly to the activities of Ringelblum and his group. The testimonies were given by people of various professions, with varying levels of education and from various social backgrounds. Children also gave their testimonies. Witnesses' accounts survive from almost all the ghettos and camps. An annotated, bilingual (Polish-English) catalogue of survivor testimonies is being published (five volumes in the years 1998-2007, with 5,000 entries).

The collection of the Central Committee of Jews in Poland (CKZP) of the years 19441950 attests to the intensive postwar efforts being made to rebuild the Jewish community in Poland after the Holocaust. CKZP also sponsored the Union of Jewish Writers and Journalists, the Society for the Advancement of the Fine Arts, the Jewish Cultural Association, the Central Jewish Library and the Union of Jewish Partisans. After the regime forced the closure of the CKZP in 1950, the Jewish Historical Institute received complete documentation regarding the activities of the CKZP's nineteen departments, its branches and other independent agencies.

The CKZP created a Register of Holocaust Survivors during the years 1944-1947, which contains basic information on approximately 250,000 individuals: their and their parents' names, place of residence before and after the war and place(es) they survived the war. It is being processed and will be soon accessible as a data base.

\section{- LIBRARY}

It is the only library in Poland specializing exclusively in Jewish subject matter. The library continues in the tradition of the Main Judaic Library. The collection is based on volumes 
gathered during the years 1944-1949 in the Central Jewish Library, including fragments that were recovered from the Main Judaic Library, the libraries of the Jewish Theological Seminary in Breslau (Wrocław) and the Yeshiva of the Sages of Lublin, as well as other private and public Jewish libraries. The collection of manuscripts and old prints includes items from libraries and archives in Warsaw, Berlin, Vienna, Prague and Wroctaw that were looted by the Germans and hidden in Lower Silesia, and then found again after 1945. The library currently holds over 80,000 volumes including over 2,500 periodicals (from the early $19^{\text {th }}$ century up to current titles), and rare books collection of manuscripts and prints published before 1800. The collection is constantly growing, thanks to new acquisitions, gifts and interlibrary exchanges. The Jewish Historical Institute Library is the only one in Poland to have a separate catalogue of books and journals in Hebrew and Yiddish, in their original alphabet.

The abundance and diversity of Jewish press in prewar Poland was astonishing. Not only cities, but almost every town had its own local Yiddish newspapers and journals.

Jewish newspapers and periodicals were issued in Warsaw from 1823 in Polish, Yiddish, Hebrew and German, numbered several hundred titles; Haint appeared in 1908 and next to Moment was the most widely read daily paper in Yiddish. The most important Polish-language newspapers were Izraelita (1866-1915) which promoted the assimilation of Jews into Polish culture, and Nasz Przegląd (1920-1939), tending toward Zionism.

Among the old manuscripts, books and periodicals are the following interesting items:

Book of Eldad ha-Dani, North Africa, 9-10 $0^{\text {th }}$ century This is the oldest manuscript in the collection. It is a single sheet of poorly tanned parchment, with 24 lines of Hebrew text, being a fragment of the Jewish traveller's account of his 880-883 journey to Jewish communities in Palestine, the Euphrates and Tigris valley, North Africa, and Spain.

Isaac ben Josef Israeli: Yesod olam. A $15^{\text {th }}$ century copy of 1310 work, by Abraham ibn Natan, in Hebrew, on paper. It contains the first known description of the parallax calculation method and includes many sketches and astronomical tables.

Israel ben Moshe ha-Levi of Zamosc (ca.1700-1772) : A Commentary to Liber Cosri by Yehuda Halevi.- $18^{\text {th }}$ century - Hebrew, German, on paper. Transcript was done by Moses Mendelssohn, then student of the author.

Elia Levita Bachur (1468/69-1549) : Thisbites. - printed in 1541. The first edition of the Talmudic lexicon with Hebrew phonetics and pronunciation for German and Italian Jews of the period.

Tzvi Hirsh ben Hayim : Sefer Tzemach le-Avraham : chiburo al ha-Yalkut Shim 'oni. The first Hebrew book printed in Warsaw in 1796.

Pięcioksiag Mojżesza $=$ Torat Moshe / Księga Mojżesza, Kraków 1895. Bilingual edition of the Pentateuch with Polish translation by lzaak Cylkow (1841-1908), author and preacher. Cylkow was the first Jew to publish his translation of the Bible into Polish. 
Periodicals include, for example:

Dostrzegacz Nadwiślaniski = Der Beobachter an der Weichsel. - Warszawa 1823-1824. The first Jewish periodical in the Kingdom of Poland, published in Warsaw in Polish and GermanYiddish.

Sulamit : eine Zeitschrift zur Beförderung der Kultur und Humanität unter der jüdischen Nation. - Dessau 1808. The first Jewish periodical in German, initiated in 1806 by David Fränkel (1779-1856) and Joseph Wolf (1762-1826) to promote the ideas of Haskalah.

Yung-Yiddish. - Lódź 1912. Review edited by the vanguard artistic and literary group active in Lodz in 1919-1920.

Velt-Shpigl.--Warszawa 1930. This popular Yiddish weekly was published January 1927 through August 1939 by the same co-op as the Haynt daily.

Gazeta Żydowska. - Kraków 1940-1942. The only newspaper sanctioned by the German occupying authorities; published 1940-42.

It was difficult to present the most interesting $20^{\text {th }}$ century books in Yiddish. Here is the selection:

S. An-ski, Tzvishn tzvey veltn oder der dybuk [Between two worlds or the dibbuk]. Vilna 1919 - with the author's autograph dedicating the copy to the known actor Abraham Morevski ; probably the first book edition of the famous play in Yiddish. The original YiddishRussian version of The Dybbuk was lost and An-ski had to re-create his work using the Hebrew version published by Chaim Bialik in 1918.

Izkor : a denkmal di gefalene shomrim un arbayter in Erec Israel [Memorial for fallen shomrim and workers in Erec Israel], Lódż 1918. The book in remembrance of Jewish settlers killed in Palestine in Arab-Jewish riots.

Yung Shikago, 1922. Compilation of Yiddish verse of Chicago based poets under the title with reference to the Yung Yiddish group active in Lodz in 1919-1922.

Abraham Goldfaden: Shulamit, New York 1928?. American edition of a major hit of Yiddish theatre in Poland in early $20^{\mathrm{th}} \mathrm{c}$.

Emest Luninski, Berek Joselewicz, Kock 1928. The book was published simultaneously in Polish and Yiddish to commemorate the 125th death anniversary of the Jewish hero of the Kosciuszko uprising against the Russian invasion against Poland.

Henryk Sienkiewicz, On a gloyben [Without a Dogma], Warszawa 192?. Since Jewish readers were also seeking Polish literature, the publishers contracted Yiddish translations of Polish novels, short stories, and dramas.

Sinclair Lewis, Babbitt, Warszawa 1930. Yiddish publishing was always up-to-date: here is a translation of a contemporary American novel of the 1930 literary Nobel prize winner. 
Kalman Gutenboym, Relativitet teorie, Warszawa 1923. Another example of Jewish authors keeping pace with the world: a Yiddish book on Einstein's relativity theory, following his Nobel prize (1921).

The twists and turns of the fortunes of Jewish books are to be deduced from numerous stamps, labels, inscriptions, and plates. Beside libraries in big cities, like Warsaw, Kraków, or Lódź, we see names of numerous people and towns all over Poland: Konin, Sieradz, Płock, Chełm, and many others.

\section{- MUSEUM (ART COLLECTION)}

The collection with its over 11,000 Jewish-related items is recognized in Poland and abroad. There are ritual objects and also paintings, sculptures and graphics, collected mainly by the Jewish Society for the Promotion of the Fine Arts, re-established after WWII and closed by the communist regime in 1950. There are also historical mementos, for the most part objects from the ghettos and camps, including the emblems of discrimination, such as armbands and patches with the Star of David, signs, notices and food ration cards. The bulk of the collection is comprised of items acquired in the first years after WWII. Later, items donated to the museum were added, as well as bequests and - less frequently, for lack of funds - objects purchased for the collection. The pieces from the collection are also loaned to other museums for exhibitions both in Poland and abroad.

Ritual objects include silver containers for spices, Hanukkah lamps, candlesticks and wine goblets, mainly of the nineteenth century. There are numerous objects made by Warsaw goldsmiths, from the workshops of Hersh Szyldberg, Yankel Kelmer, Shmul Szkarłat, M. Charłap and Abraham Reiner, and from non-Jewish firms, such as those of Jan Pogorzelski, Karol Filip and Antoni Riedl; by Berlin goldsmiths: Joachim Hübner and Johann August Gebhardt; by Wroclaw goldsmiths: Georg Kahler Jr., and by a Russian goldsmith Pavel Sazikov. In addition to handmade objects, there are also mass-produced ones, such as silver-plated Hanukkah lamps, spice containers, and candlesticks from the Warsaw factories of Norblin, Fraget, B. Buch, S. Handelsman and I. Zylberberg. Textile collection includes about 80 parokhot (Torah ark curtains), of which particularly interesting is the one depicting lssac's Sacrifice, made in Lower Silesia and dating back to 1774. One of the most interesting objects is a restored fragment of the Torah ark, most probably from some small Warsaw synagogue. There have been over 400 of them before 1939 and almost no trace remained, therefore this ark has not only its own esthetic value but also symbolic meaning. Conservation of valuable artifacts and the exhibition's technical equipment were financed by funds from a bequest of Dr. Jack Burton Weissman of New York.

Among the most important $19^{\text {th }}$ century paintings there is a Head of an Old Man, by Maurycy Gottlieb (1856-1879), considered the first professional Polish Jewish painter, and also a copy of his self-portrait in the Arab costume, painted by his younger brother Marcin (1867-1936; the original has been lost). Another masterpiece of that period is Samuel Hirszenberg's (18651908) Artist and his Muse. Most of the paintings, however, is from the 1920s and 1930s. Their authors were well known in the general artistic community in the inter-war Poland, especially in 
Warsaw, Lodz, Wilno, Lwow and Cracow. The most distinguished artists were Artur Markowicz (1872-1934), Maurycy Trębacz (1861-1941), Artur Nacht-Samborski (1898-1974), Jan Gotard (1898-1943), Roman Kramsztyk (1885-1943), the twin brothers Efraim and Menasze Seidenbeutel (1903-1945), Jan Gotard (1898-1943), Eliasz Kanarek (1901-1972) and many other. The majority of the artists whose works we have in our holdings perished in the Holocaust.

A particular collection is composed of mementos from the Lodz Ghetto. In $1939 \mathrm{Lodz}$ had the second major Jewish community in Europe, over 233,000 people who constituted almost $35 \%$ of the entire city population. The ghetto was established by Germans in the spring of 1940 . Its inmates, whose number amounted to 200,000, included not only Jewish inhabitants of Lodz and its environs, but also from Austria, Czech Republic, Luxembourg, and Germany. Most of them perished at Kulm [Chelmno on the Ner] and Auschwitz-Birkenau. In May and June of 1942 the Lodz agency of the Frankfurt based Nazi Party Institute for the Study of the Jewish Question established the Wissenschaftliche Abteilung [Scientific department] in the Lodz Ghetto. Its major objective was to set up a museum staging the image of the Jewish people in keeping with the Nazi doctrine. The Department employed 35 Jewish painters, sculptors, and graphic artists. Only a few are mentioned here: Vincent (Icchak) Brauner, Hersz Schillis, Józef Kowner, Izrael Lejzerowicz whose paintings portrayed everyday life and also particular events in the ghetto. Also the documentation required by Germans remains today a testimony of the ghetto life, like two albums presenting hats and carpets manufactures.

Another kind of testimonies are albums presenting the German police in the Lodz ghetto. They were discovered in 1945 at a villa in Bydgoszcz, upon the return of its Polish owners, who had been expelled by the Germans in 1939. The albums must have been left by the Police Chief in Lodz, SS-Brigadefürer Dr. Karl Albert on the run from the advancing Soviet army. The author of the albums was a policeman Steiner. Album No.1: Lodzer Juden. 1937 und Getto keeps the following dedication, in German: "To The President of the Police Dr. Albert in remembrance of the joint efforts at solving the Jewish question in Litzmannstadt". Album No.2: Die Polizei greift durch! [Police brings order) was presented to the Commandant Albert on September 8, 1942. Along the photos Steiner added cuttings from the crime column of the German newspaper Deutsche Lodzer Zeitung concerning local Jewish crime, reputedly restrained by the establishment of the ghetto.

Although most of the ritual objects described above belong to Ashkenazic rite, there are also Sephardic ones. The latter are memorabilia of Greek Jews who perished in the extermination camps in Auschwitz and Majdanek. Before WWII the Jewish community of Greece had about 71,000 people. Most of them lived in Thessaloniki. Upon the outbreak of WWII Greece remained neutral, but attacked by Italy on August 15, 1940, joined the Allies. On April 6, 1941 German forces launched an invasion of Greece and captured its territory within two months. The Holocaust reached the Greek Jews in 1943. The first to die at the Treblinka killing center in February were the Jews from the Greek parts of Macedonia and Thracia annexed by Bulgaria. Between March 15, 1943 and August 1944, Germans deported and murdered at Auschwitz-Birkenau 59,000 Jews of Thessaloniki and Athens. Another transport of 542 men and 302 women was sent to Majdanek in early June 1943. The deportees did not have any idea they were going to 
their death and thus carried all the implements for religious observance. Some of these objects were bestowed to ZIH in 1948 and 1951 by the Polish Ministry of Culture.

\section{- DOCUMENTATION OF HISTORICAL SITES}

This department is involved in the collection and publication of information about historical sites of Jewish material culture related to Jewish quarters, synagogues and cemeteries. Information includes descriptions, maps and photographs, films and sound recordings which illustrate the life of the Jews in Polish lands, in towns big and small as recorded in diaries, historical studies, press publications. The number of photographs from the years 1860-2003 amounts to approximately 40,000 . Documentation comprises objects of Jewish culture that have survived, such as headstones from approximately 400 cemeteries. There are also photographs of approximately 320 synagogues and houses of prayer that still exist in Poland today. One of the tasks is to collect documentation about historical sites that have been destroyed. The collection is constantly growing through gifts and donations and less frequently by purchasing items at auctions.

Although this department was established only in 1991, it was already in the early 1950s that several photographers were hired by the director of the Institute to document whatever remained of Jewish communities in towns and villages: synagogues, cemeteries, Jewish quarters. This collection of about 5,000 photographs helps us to establish what was still remaining after the Second World War and what was lost since the pictures were taken.

In 1990-1995, we had a special opportunity provided by the World Monuments Fund, to document cemeteries in Poland. The information was collected over a period of four years in the site survey organized for this project. As a result, 1008 cemeteries have been identified (the previous databases listed up to 400 of them), and of them 855 were visited and described in a unified way with the help of the special survey form. It has been found out, at that time, that on 487 cemeteries gravestones survived, starting from onestone up to over 5000 (the biggest ones being in Lódz with 200.000 and in Warsaw, 150.000 estimated). The total list of cemeteries today is over 1200 , however, only those with matzevot can provide us with information on people buried there.

The photographic documentation of the social life of Polish Jews includes both original family photographs, as well as reproductions from periodicals, beginning with the period before the First World War. There are also photographs of Jewish political and social activists from 1918 1950.

Warsaw has a special place in this department. There is documentation of the pre-war life of its Jewish community, the second biggest in the world (next to New York), with its complicated history reflected also in the settlement patterns in the town, starting in the late $18^{\text {th }}$ century. There is also a history of the ghetto, its struggle for life and its destruction. Photographs from Jewish Warsaw are organized by streets, so that one can compare their view and see their fate at different time. 
In many Polish towns, memorials are the only reminders of the Jewish presence. This Department gathers documentation regarding their erection and related ceremonies, sponsors and participants. This documentation provides information on the involvement on the one hand, of various Jewish foreign organizations, the landsmanshaftn first and foremost, and on the other hand, the local authorities, schools, teachers and various civic organizations in Poland. Basing on this documentations, the awards are given every year to non-Jewish individuals and organization who actively help protecting Jewish heritage in Poland.

\section{- RESEARCH, EDUCATION AND PUBLICATION}

Beside the care of collections, research, education and publication are the main activities of the Institute. The research on the Holocaust conducted immediately after it was over made the Institute the pioneer institution in this domain. The results were used immediately in the war crimes trials, including the largest, in Nuremburg. The research on the Holocaust continues in the Institute, however, according to Bernard Mark's declaration of 1950 (see above) it covers also other fields of the almost one thousand years long Polish Jewish history and culture: condition of the Jewish population in Poland and Jewish-Christian relations, starting in the beginning of the Jewish settlement until 1939; Jewish cultural and spiritual life, including Jewish art; fate of the Polish Jews after WWII; and methodology of teaching about Jewish presence in Poland. Weekly academic seminars take place at the Institute, as well as national and international conferences. The Institute participates in several academic programs run jointly by Polish and foreign institutions.

The Institute used to publish two academic journals, the already mentioned Biuletyn Zydowskiego Instytutu Historycznego [Bulletin of the Jewish Historical Institute], published in Polish beginning in 1950, and the Bleter far geshikhte [Pages of History], published in Yiddish beginning in 1948. The second one was closed in 1993. The first one changed its name in 2001 into Kwartalnik Historii Żydów/Jewish History Quarterly, and now it publishes also in English and German. The Institute publishes works by its own staff members, as well as authors from other institutions. These books are scholarly monographs, anthologies of primary source materials, popular editions, catalogues of exhibitions, guidebooks and archival catalogues. In 1997, a new publishing series was inaugurated, titled Memoirs, Testimonies, Diaries, which numbers approximately thirty volumes to date. Each of them presents a different aspect of Jewish life in Poland.

Since 2000, the Institute has run an "Open University" - a regular monthly series of public lectures on the history of the Jews, their religion and customs, and on Polish-Jewish relations. Classes are also organized for school groups, which are conducted by the museum staff and the research section, who help young people to become acquainted with the history, art and religious traditions of the Polish Jews. The museum's employees also organize lectures on Jewish art for students from the Academy of Fine Arts in Warsaw. The Institute organizes national competitions for the best master's theses and doctoral dissertations on Jewish subjects. It also participates in competitions on Jewish history and culture for high school students run by the Shalom Foundation 
under the aegis of the Ministry of National Education. In addition, and not systematically, the Institute sponsors Hebrew and Yiddish language courses.

In 2008 , marking the $65^{\text {th }}$ anniversary of the Warsaw Ghetto Uprising, the research was focused on the less known aspects of the Uprising, and especially on the history of the rightist Jewish Military Union, much less known than the leftist/Zionist Jewish Fighting Organisation.

This year we also marked the 40th anniversary of the so-called "March events" of 1968 . The rich documentation is being collected which will enable researchers to study this last expulsion of the Jews in the post-war years.

Another activities of the Institute are tightly connected to the collections, especially to those containing personal data, and documenting sites and their history:

\section{- RIGHTEOUS AMONG THE NATIONS OF THE WORLD}

This Section used to prepare documentation for the Yad Vashem Institute in Jerusalem regarding Poles who rescued Jews during the Holocaust. Yad Vashem, on the basis of these documents, bestows the "Righteous Among the Nations of the World" award. Yad Vashem has already honored over 16,000 citizens (among them about 6000 Poles) of countries that were occupied by the Nazis with this distinction. The Section cooperates with the Jewish Foundation for the Righteous in New York. The Institute is creating a database of both the rescuers and the rescued. From 2003, the documentation is included in the Archive collection.

\section{- DOCUMENTING INDIVIDUAL VICTIMS OF THE HOLOCAUST}

The Section's task is to document the fate of the Polish Jews who were living in areas occupied by the Germans. The documentation is provided solely for the needs of interested parties, for example, the former inmates of concentration and forced labor camps and ghettos, also for restitution claimants. Because the personal information is protected by law, it will be made public knowledge for research purposes after the legal waiting period has passed.

\section{- THE RONALD S. LAUDER FOUNDATION GENEALOGY PROJECT}

The Ronald S. Lauder Foundation sponsors the activities of this Project, which helps Jews from all over the world search for their roots in Poland. People who turn to the Project for help still have hope that their family members are alive, as do those who have just recently discovered their own Jewish roots, and who now wish to learn more about their ancestors. Thanks to the Institute's archival resources and databases, it sometimes proves possible, even many years later, to find that information. In many cases, the Project's efforts have led to the reunion of family members who have been scattered all over the world. Funds from donations of those using the Project's services help furnish the Institute with necessary equipment or in the restoration of documents. 
The holdings of the Jewish Historical Institute are the reminder of the thriving Jewish life and culture in prewar Poland, the site of the largest Jewish community in Europe before WWII. Our documents, books, and artifacts can provide for the insight and understanding of the life and death of Polish Jews and the destruction of European Jewry in the Holocaust. Even these holdings which date back to early periods are testimonies to the Holocaust because that they show how little was left in Poland, once the country of Jewish population of 3.5 million. The books in our library do not only tell us how rich the Jewish literary life was but also testify to how many libraries were destroyed. The joyful and peaceful paintings and sculptures, when we consider the dates of death of their authors, not only show us how they contributed to art but also make us think what would those people have accomplished were they not killed. 